Ecological Research (1998) 13, 105-116

\title{
Patterns and mechanisms of transpiration in a large subalpine Norway spruce (Picea abies (L.) Karst.)
}

\author{
Karl Martin Herzog, ${ }^{1}$ Roland Thum, ${ }^{1}$ Gerhard Kronfub, ${ }^{2}$ Hans-Jakob Heldstab ${ }^{3}$ \\ AND RudolF HÄSLER ${ }^{1 *}$ \\ ${ }^{1}$ Swiss Federal Institute for Forest, Snow and Landscape Research (WSL/FNP), CH-8903 Birmensdorf, \\ Switzerland, ${ }^{2}$ Institute of Botany, University of Innsbruck, Sternwartestr.15, A-6020 Innsbruck, Austria \\ and ${ }^{3}$ Department of Ecology, University of Zürich, Winterthurerstr. 190, CH-8057 Zürich, Switzerland
}

In situ water relations of a large subalpine Norway spruce (Picea abies) were analyzed by simultaneous measurements of sap flow at different crown positions. In the diurnal scale, transpiration varied greatly, both spatially and temporally. Over longer periods, however, different parts of the crown transpired in fairly constant proportions. The average estimated transpiration was about 3.5 times greater in the upper than in the lower half and decreased 1.6-fold from south to north. Water intercepted from rain, fog and dew buffered and significantly decreased the transpiration. The effect was strongest in those parts which were least coupled to the free atmosphere. The top of the crown seemed to experience a regular shortage of water shortly after starting transpiration, when it was forced to switch from internal reserves to sources in the soil. Further, lower branches then started transpiring, which may have led them to compete for the water. An enhanced nocturnal sap flow during warm and dry winds (Foehn) indicated that the tree also transpired at night. Shaded twigs had more capacity to intercept water externally than twigs in the sun. The significance of the crown structure for interaction with water in both liquid and vapour phases is discussed.

Key words: crown structure; interception; Picea abies; transpiration mechanism; sap flow.

\section{INTRODUCTION}

Transpiration in large trees with well-structured canopies varies spatially and temporally (Hinckley et al. 1978). It is determined by the weather and the position of transpiring twigs relative to the free atmosphere and the water source. Since the position of the twigs within the canopy varies greatly, they adapt structurally and physiologically to the specific demands of their locations (Brehmer 1981; Schoettle \& Smith 1991).

If the twigs are maladapted or if evaporative forces at their location exceed the usual range of variation, they may be overstrained and injured (Kozlowski 1979). This may be due to extraor-

\footnotetext{
*Author to whom correspondence should be addressed.

Received 22 July 1997.

Accepted 25 December 1997.
}

dinary weather, but it can also arise from a change in the structure and hydraulic architecture of the canopy (cf. Matyssek et al. 1991) since the twigs may be highly interdependent as they are bunched together, overlap and also share the same water source. Hence, the water relations of such crowns are complex. Understanding the processes involved, particularly with respect to different parts of the crown (e.g. the dieback of twigs or the apex, loss of particular leaves), requires more insight into the major mechanisms of their overall water balance, such as water distribution in twigs with different demands. However, little is known about these mechanisms.

One reason for this lack of knowledge might be that up to now the main interest in tree transpiration has been for hydrological purposes. Many studies have focused on up-scaling transpiration from trees to whole stands or regions in order to obtain estimates of areal evapotranspiration. Such integrative approaches (e.g. Balek et al. 1983; 
Granier 1987), which have often been combined with indirect methods for determining evapotranspiration (e.g. Black 1979; Valentini et al. 1989; Diawara et al. 1991), have generally paid little attention to the single crown. Another reason for the scanty knowledge about large crowns may have been the cost of exploring them (e.g. requiring scaffolding or a hoisting apparatus). Furthermore, the measurement of natural transpiration in situ on branches or twigs is still an experimental adventure. Available methods are limited. The common technique for determining the transpiration of leaves by gas exchange, for instance, is applicable only to dry canopies (cf. Jarvis \& Catsky 1971) and provides poor information about crowns that are frequently wet. However, approaches which can also cope with wet crowns (e.g. Vogt \& Jaeger 1990) may only be used with complete canopies. Thus, they are inappropriate for studies of individual crowns. Also scaling down from stands to single crowns or even parts of them is at least as problematic as vice versa (cf. Denmead 1984; Baldocchi 1989).

One way of assessing the transpiration of single crowns or parts of them under natural conditions is to measure the sap flow in stems (Sakuratani 1984; Granier 1985). Over all, the sap flow estimates total transpiration well, apart from temporarily changing influences of tree internal buffers. Although the heat balance technique is often used, it still has some experimental difficulties. Depending on the thermal conductance of the surroundings, the heat in the stem dissipates quickly, especially under conditions with low sap flow (cf. Gerdes et al. 1994; Gutierrez et al. 1994; Herzog et al. 1997). Therefore, the techniques for such measurements are subject to continuous improvements (Swanson 1994). We used the method with the aim of elucidating the patterns and mechanisms of natural transpiration in a large subalpine Norway spruce.

\section{METHODS}

\section{Tree and site description}

Sap flow was measured within the crown of a 220-year-old Norway spruce (Picea abies (L.) Karst.) during the 1992 growing season. The tree was growing on ferric humic podsol in a subalpine larch-spruce forest (Larici-Piceetum) $1639 \mathrm{~m}$ above sea level near Davos (Switzerland). Its crown was made accessible by a transparent scaffolding. The map of crown projections in Fig. 1 shows the topographical situation and the canopy structure of the experimental site. Figure 2 shows the vertical distribution of the total needle surface along the analyzed crown. This consisted of two stems which were connected with each other at the base and diverged up to $1 \mathrm{~m}$ on the top of the crown. The double-stemmed tree of $P$. abies is usually found at the subalpine study site and was selected as a model crown for the investigation of water relation.

\section{Measurement of sap flow in xylem}

Sap flow in the xylem was measured on the basis of the heat balance within the tissue of the stem (Čermák et al. 1973; Kučera et al. 1977; Čermák \&

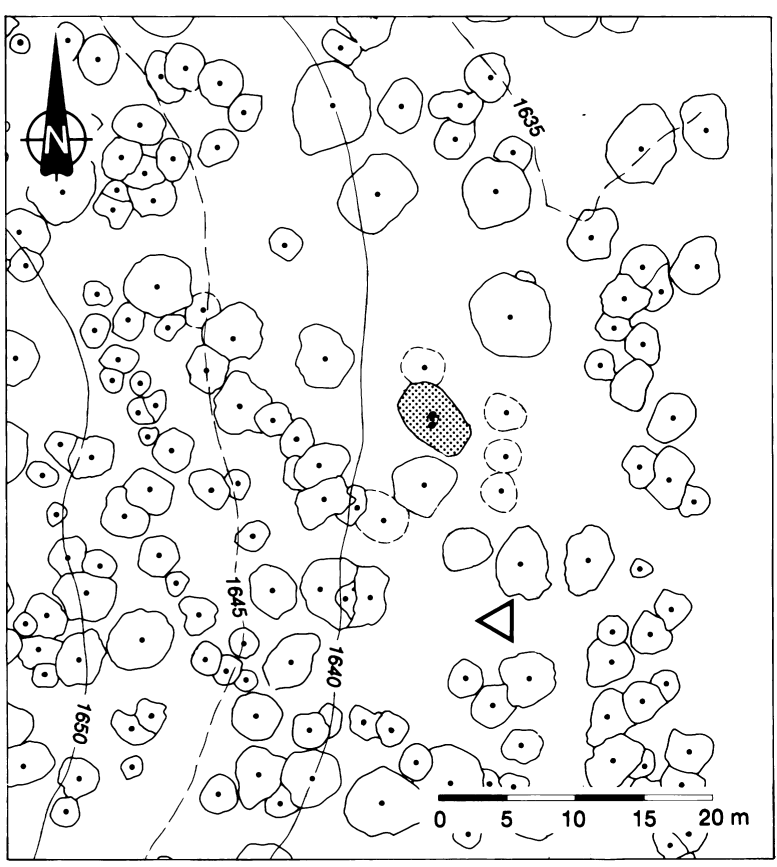

Fig. 1. Map of crown projections of the stand including the experimental tree (dark crown). Note that the top of the experimental tree would reach the right border if it was cut down. This provides a perspective for the third dimension. The meteorological tower (triangle) and the relief of the site (solid and dashed lines; elevation in $\mathrm{m}$ a.s.l.) of the site are indicated (adapted from Stark et al. 1991). 
(a)

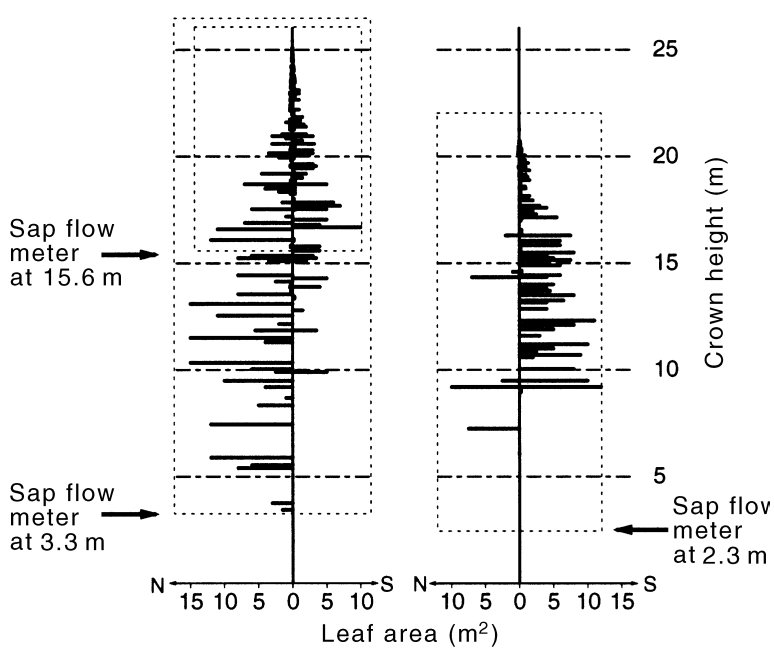

Fig. 2. Distribution of total needle surface within the double-stem crown. (a) Stem N (north) and (b) stem S (south) originated from one root-stock. Needle areas of branches pointing in $\mathrm{W}-\mathrm{N}-\mathrm{E}$ direction are plotted towards the north and vice versa. Positions of the sap flow meters with respect to the corresponding parts of crown are indicated (adapted from Häsler et al. 1991).

Kučera 1981) using the sap flow meters, WAFL1 (Gröger S.E.P., Bayreuth, Germany). Since the measurements were initially not realistic, they were adjusted by reference to the gauge SGB 25 for stem heat balance (Dynamax Inc., Houston, TX, USA; Sakuratani 1984). Parameters for this adjustment were derived in situ by comparing the two techniques in the upper half of the crown (Herzog et al. 1997). Flow meters were placed $3.3 \mathrm{~m}$ and $15.6 \mathrm{~m}$ above ground (base and midcrown) on the north stem and $2.3 \mathrm{~m}$ above ground (base) on the south stem (Fig. 2). The total area of needle surface on the north stem (stem N) was estimated to be $447 \mathrm{~m}^{2}$ (Häsler et al. 1991). About half of it $\left(218 \mathrm{~m}^{2}\right)$ was above, the other half $\left(229 \mathrm{~m}^{2}\right)$ below the upper flow meter. On the south stem (stem $\mathrm{S}$ ), the needle surface was estimated to be $299 \mathrm{~m}^{2}$. The daily flow of sap was calculated for the period between 0 and $24 \mathrm{~h}$.

\section{Determination of the water content and water deposition capacity of twigs}

Twigs of the current year (1992) were cut from different positions in the crown and immediately enclosed in small plastic bags. After each har- vesting, conducted at 2-hour intervals from 0 to $24 \mathrm{~h}$ on 19 August, the fresh weights $\left(W_{f}\right)$ of the enclosed twigs were determined using a portable electronic balance (BA110, Sartorius, Goettingen, Germany). The twigs were stored at $-25^{\circ} \mathrm{C}$ until their capacity for water deposition was determined in the following way: while still enclosed in bags, they were equilibrated to laboratory temperature, unpacked, weighed $\left(W_{0}\right)$, submerged horizontally in distilled water for $1 \mathrm{~min}$ with the sun-oriented side facing upwards. They were then slowly lifted out and immediately weighed again $\left(W_{i}\right)$. The dry weight $\left(W_{d}\right)$ was determined after drying them at $80^{\circ} \mathrm{C}$ for 3 days. Their internal water content $\left(C_{w}\right)$ and their water deposition capacity $\left(D_{w}\right)$ were calculated according to equations 1 and 2, respectively:

$$
\begin{aligned}
& C_{w}=W_{f}-W_{d} \\
& D_{w}=\frac{W_{i}-W_{0}}{W_{f}}
\end{aligned}
$$

\section{Environmental measurements}

The matric water potential in the soil was measured along two transects across the rooted area of the experimental tree. A total of 42 tensiometers were installed at depths of $0.1 \mathrm{~m}, 0.35 \mathrm{~m}$ and $0.8 \mathrm{~m}$, with 14 at each level. The weather was recorded at the top of a $35 \mathrm{~m}$ tower near the tree (cf. Fig. 1).

\section{RESULTS}

Figure 3 shows two contrasting patterns of diurnal sap flow at the three crown positions. On the first day (28 August), rain fell on the crown in the early morning. The wind blew from the south and its velocity increased during the day. This wind, in combination with the solar radiation, caused intercepted water to evaporate rapidly from the southern part of the crown. Consequently, this part transpired freely, whereas sap flow in stem $\mathrm{N}$ increased only gradually during the day. The daily flow in stem $\mathrm{S}$ reached $88.4 \mathrm{~kg}$, compared to $42.6 \mathrm{~kg}$ in stem $\mathrm{N}$, although the corresponding transpiring needle surface was only $299 \mathrm{~m}^{2}$ for stem $\mathrm{S}$, compared with $447 \mathrm{~m}^{2}$ 


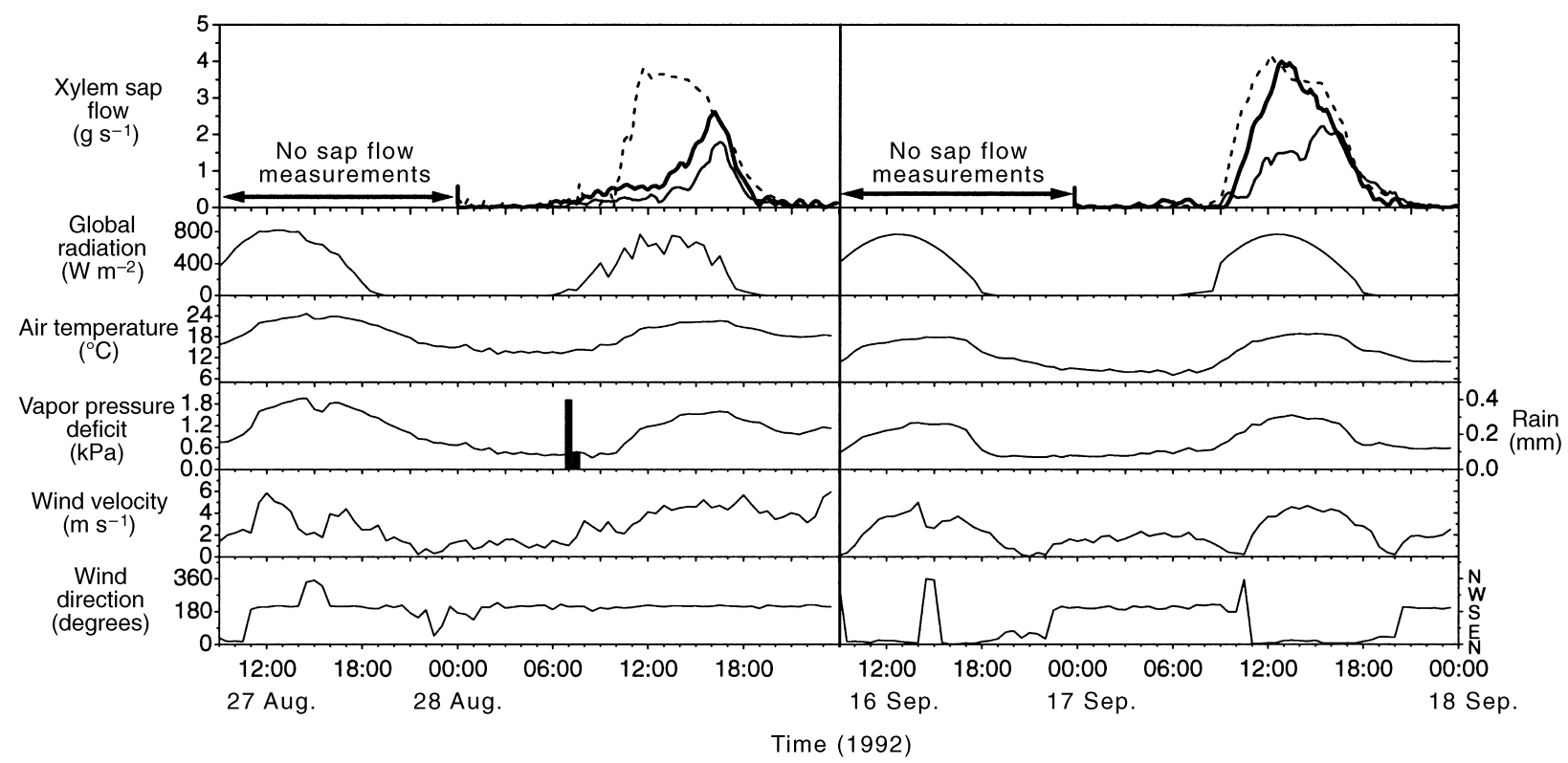

Fig. 3. Diurnal variations in sap flow measured at the base (-) and in the middle (-) of stem $\mathrm{N}$ and at the base of stem S (---) on 28 August and 17 September 1992. The transpiration patterns of the two days differed greatly because of the difference in the weather and the interception of water. Weather factors shown are: global radiation, air temperature, vapor pressure deficit, wind velocity, rain, and wind direction.

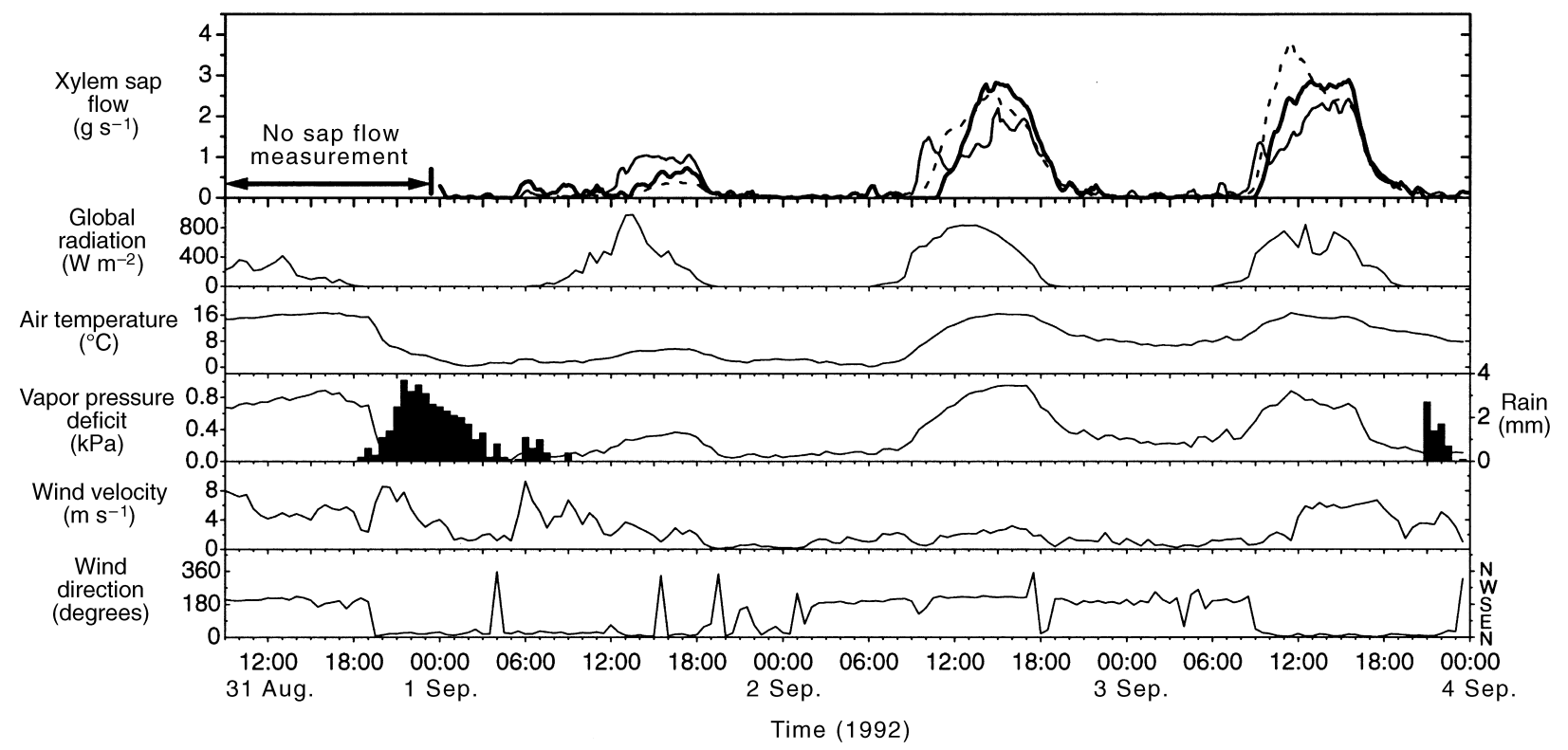

Fig. 4. Diurnal variations in sap flow measured at the base (-) and in the middle $(-)$ of stem $\mathrm{N}$ and at the base of stem S (---) from 1 to 3 September 1992. Flows show the start of transpiration in the drying crown. Weather factors as in Fig. 3.

for stem $\mathrm{N}$. The estimated daily transpiration (per unit needle area) was about three times higher in the south than in the north-facing part of the crown. On the second day (17 September), the crown was dry and the wind changed direction from south to north during the day. Thus, sap flows at the base of both stems exhibited similar diurnal patterns, and estimated transpiration was only about twice as much in the southern part of the crown as in the northern part. 
Figure 4 shows a period of three consecutive days (1-3 September) preceded by a drop in temperature and rain. Sap flows on the first day (1 September) were typical of a day after precipitation when the tree was saturated and its crown wet. They were small, and the flow in the middle of stem $\mathrm{N}$ exceeded that in the base. A little transpiration still occurred, even while it was raining in the morning, and thus peaks in wind velocity around $6 \mathrm{~h}$ and $9 \mathrm{~h}$ were reflected in sap flow through stem $\mathrm{N}$. On the second day $(2$ September), sap flows started in a loose sequence at the middle of stem $\mathrm{N}$, the base of stem $\mathrm{S}$, and the base of stem $\mathrm{N}$. This reflected the order in which internal water started transpiring from the corresponding crown parts (cf. also 28 August in Fig. 3), and in which evaporation of intercepted water had been enhanced by solar radiation: the top of the northern crown first received direct sunlight; then it was predominantly the southern half of the crown which faced the sun; finally, the transition from evaporation to transpiration took place also in the lower part of the north crown.

Some $6.5 \mathrm{~kg}$ of water, which is $13.4 \%$ of the daily amount, passed through the middle of stem
$\mathrm{N}$ even before the sap in its base started moving, which it did with a time lag of $110 \mathrm{~min}$. This cannot be due just to the different times it took for the individual crown parts to dry out. There must also have been internal reserves of water which acted as buffers in the hydraulic link between the two measuring positions. On the third day (3 September), after a relatively dry and warm night, little intercepted humidity remained in the crown, and sap flow at all positions started in quick succession.

The kinetics and proportions of sap flow measured at the base and in the middle of stem $\mathrm{N}$ varied from day to day (Fig. 5). The flow in the upper position underwent a daily temporary decline shortly after its onset. This was particularly pronounced on mornings when the crown was wet and there was a prolonged delay between the two flows (e.g. on 2, 6 and 25 September; cf. also Fig. 4). When the tree transpired greatly during daylight, evening declines in sap flow lasted until around midnight. During the night of 22-23 September this decline was significantly prolonged due to dry and warm Foehn winds (Fig. 6). The matric water potential in the soil
Fig. 5. Diurnal variations in sap flow measured at the base (-) and in the middle $(-)$ of stem $\mathrm{N}$ during September 1992: (a) 1-10 September; (b) 11-20 September; (c) 21-30 September. On mornings after precipitation there was a marked delay between the two flows (arrows). The daily decline in the flow at the upper position (circled) cannot be explained by environmental factors.

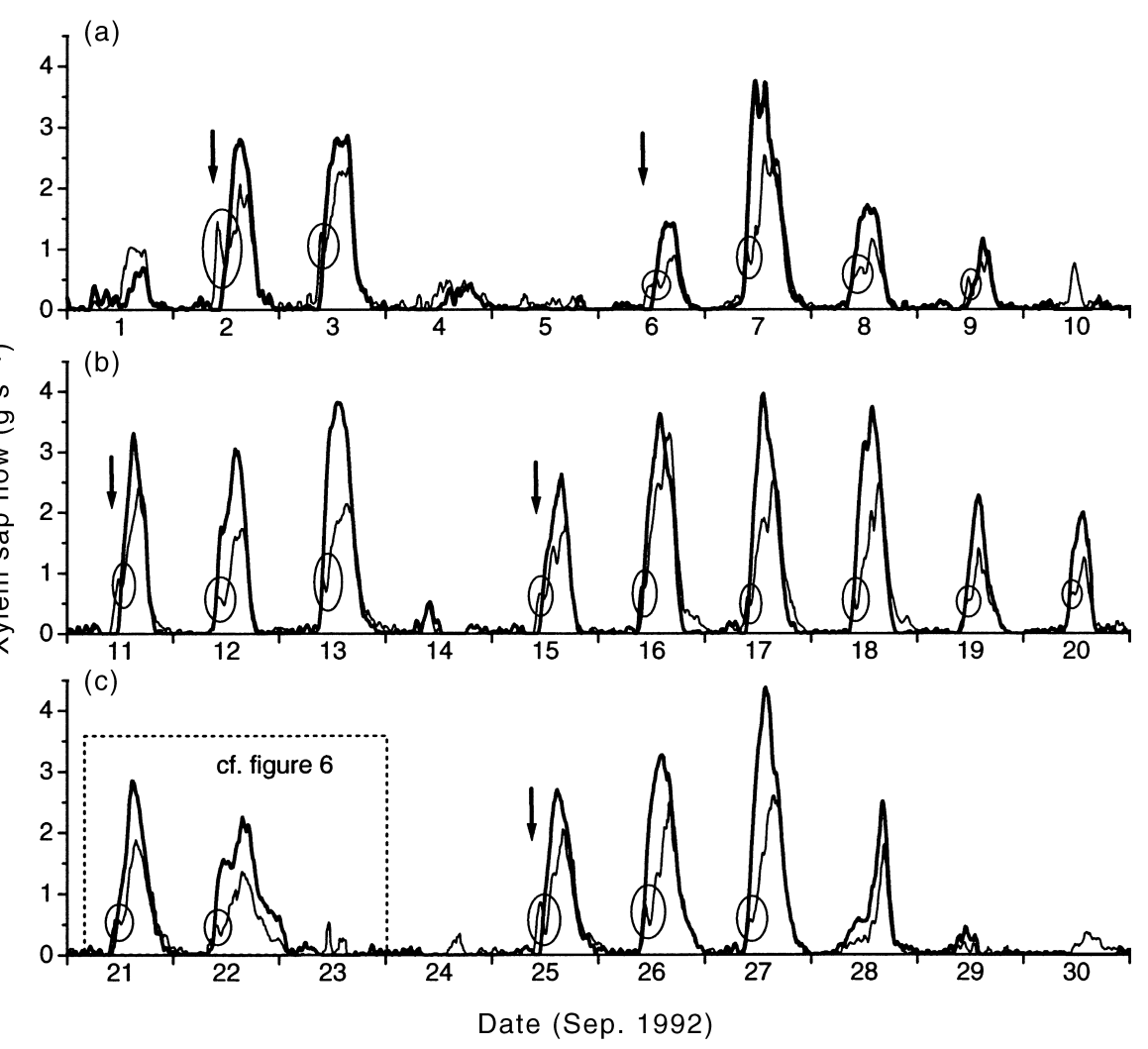




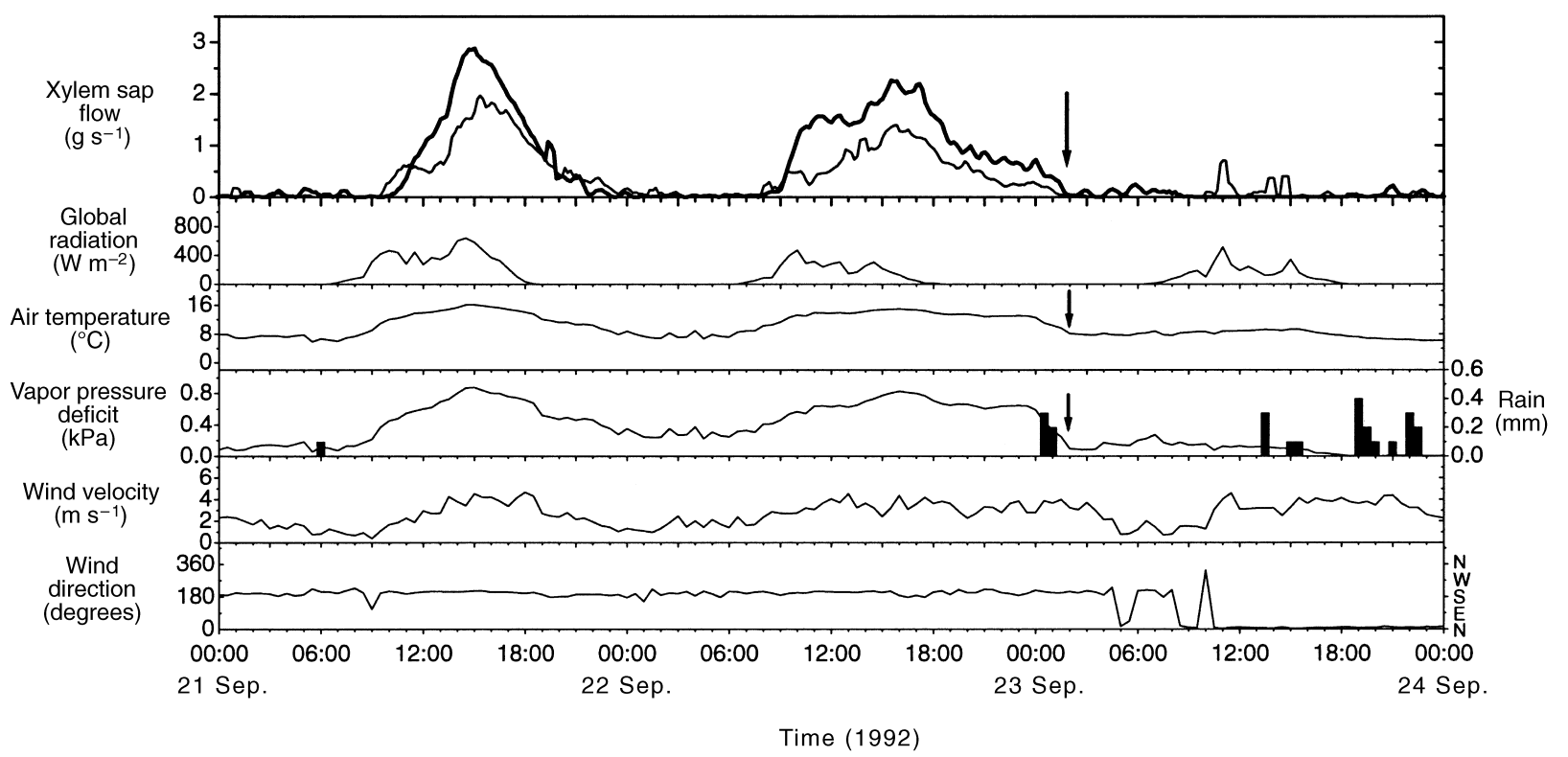

Fig. 6. Diurnal variations in sap flow measured at the base ( $\longrightarrow$ ) and in the middle ( $\longrightarrow$ ) of stem $\mathrm{N}$ from 21 to 23 September 1992. During the night of 22-23 September, sap flow lasted until the warm and dry Foehn winds ceased at $2 \mathrm{~h}$ (arrows). Weather factors as in Fig. 3.

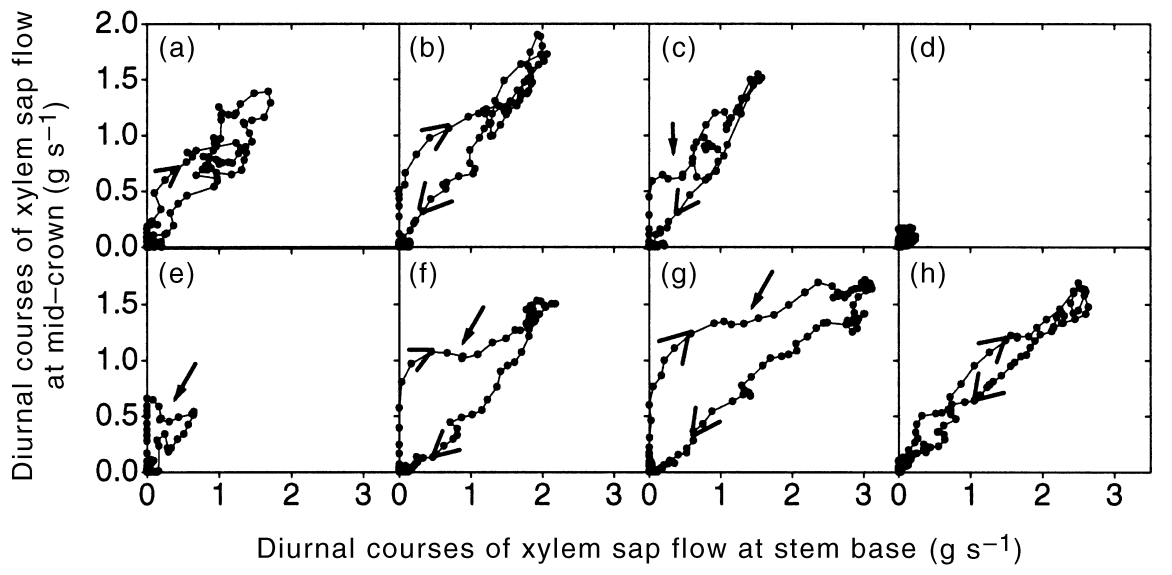

Fig. 7. Diurnal variations in sap flow measured at the base and in the middle of stem $\mathrm{N}$, plotted against each other for the days from 8 to 15 July 1992: (a) 8 July; (b) 9 July; (c) 10 July; (d) 11 July; (e) 12 July; (f) 13 July; (g) 14 July; (h) 15 July. There was frequent light rain except on 14 and 15 July. Loops became increasingly narrow during dry periods. Arrows indicate the morning declines in flow at the upper position. then was greater than $-50 \mathrm{kPa}$. The flow in the middle of stem $\mathrm{N}$ regularly reached the maximum after that at the stem base (cf. also Figs 3 and 4). The top of the crown was then still in direct sunlight, while the lower branches were already shaded by the surrounding trees.

Figure 7 shows the diurnal variation of sap flow at the base plotted against that in the middle of stem N. The period is characterized by frequent but slight daily rain. Time lags between the two flows show up as hysteretic loops. Figures $8 \mathrm{a}$ and $8 \mathrm{~b}$ compare the two sap flows over a longer period. The slightly non-linear relationship between the flow rates (Fig. 8a) may reflect some methodical bias (cf. Herzog et al. 1997). Daily flows are linearly related (Fig. 8b). If we ignore possible changes in the water stored internally in the crown as well as small nocturnal movements of sap which could not be detected by our method (Herzog et al. 1997), 77\%, on average, of the water used by the northern crown was transpired in the upper half and $23 \%$ in the lower half. Thus, estimated transpiration (referred to needle surface) was 3.5 times larger in the upper 
Fig. 8. Relationship between (a) rates of sap flow measured every $10 \mathrm{~min}$ at the base and in the middle of stem $\mathrm{N}$ $\left(y=0.012+0.92 \mathrm{x}-0.10 \mathrm{x}^{2}\right.$, $r^{2}=0.91$ ) and (b) daily flows of sap measured at the same positions $\quad(y=0.73 \mathrm{x}$, $\left.r^{2}=0.90, \quad n=45\right)$. Data represent the periods from 2 to 16 July and 1-30 Sept. 1992. (c) Relationship between daily sap flows measured at the bases of stem $\mathrm{N}$ and stem $\mathrm{S}$ during the first half of September 1992 ( $n=14)$.
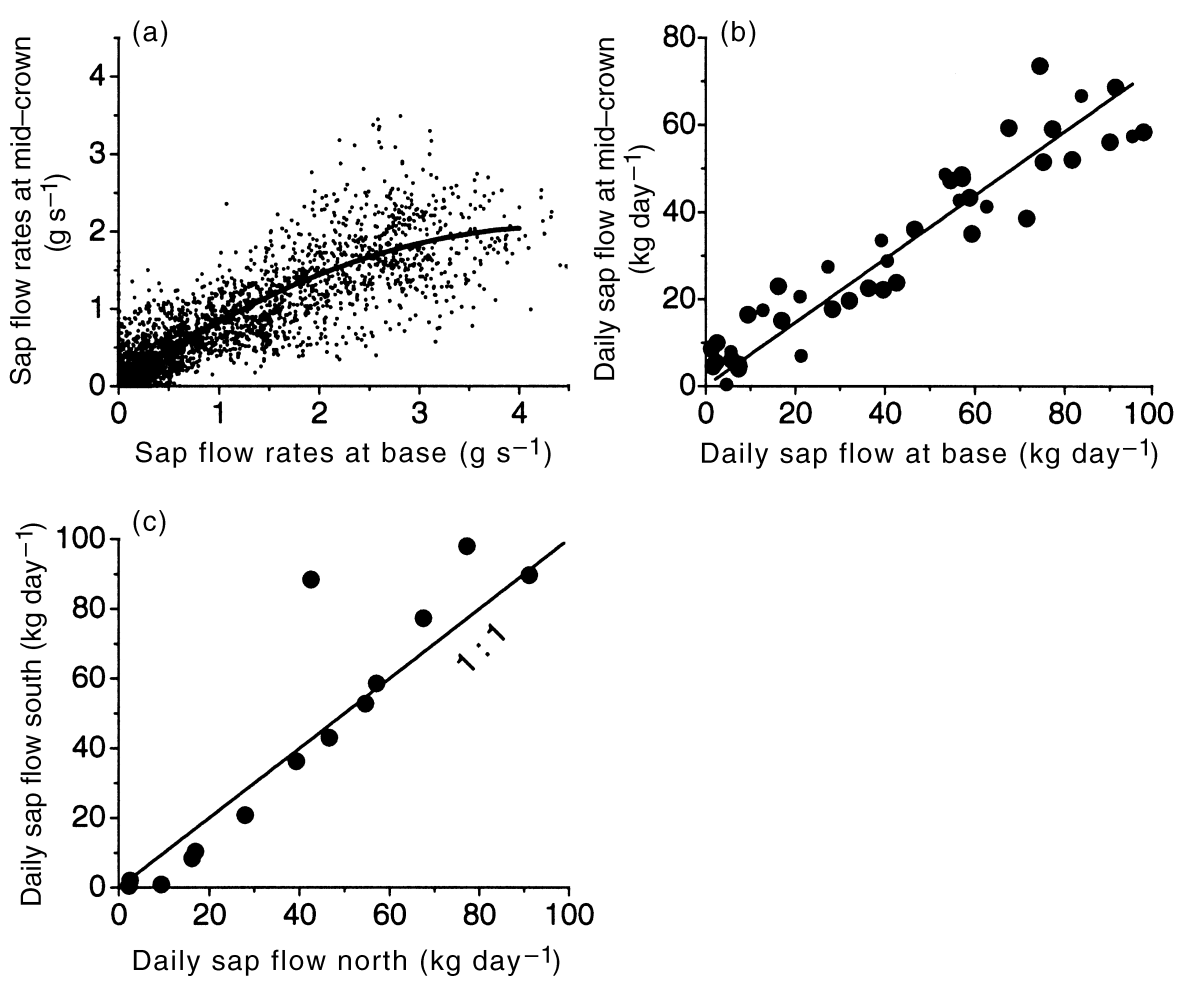

than in the lower half and, compared to the crown average, $57 \%$ larger in the upper and 54\% smaller in the lower half. The northern and the southern parts of the crown are compared in Fig. 8c. Both consumed similar amounts of water, except on days with extraordinary water interception (as shown in Fig. 3). Estimated transpiration, however, was on average 1.6 times larger in the southern than in the northern part.

The capacities for water deposition on currentyear twigs according to different heights and exposures are shown in Fig. 9. They follow a vertical gradient (Fig. 9a) and a slight horizontal northsouth trend within the crown (Fig. 9b). On the basis of their fresh weight, shade twigs intercepted more water than sun twigs, and the fairly constant ratio of water and dry matter in all the twigs (Fig. 9c) indicates further that this is also the case with respect to their internal water reserves.

\section{DISCUSSION}

Frequent rain, dew and fog are characteristic of subalpine summers and affect the water relations of the trees. Precipitation is intercepted by the crowns and so provides humidity to the microenvironments of the leaves. Under evaporative conditions, this humidity is consumed first before internal water is withdrawn from the trees, and so the trees' transpiration is suppressed and their need for water reduced.

Transpiration has been shown to decrease with decreasing needle area in the crown volume (Wang \& Jarvis 1990). However, Lovett and Reiners (1986) calculated that a decrease in needle area within a certain range would increase the interception from clouds (fog). Consequently, in foggy climates, thinning of a crown would reduce its transpiration two-fold by decreasing the transpiring surface and by increasing the interception from fog. The situation, however, seems to be different if there is rain. Beier et al. (1993) found that the greatest interception occurred in the densest parts of the crown. Thus, in rainy climates, thinning could have opposing effects: it could enhance transpiration due to less interception and reduce it through a smaller transpiring surface. Interception therefore seems to be potentially limited by both a large crown density, as this may obstruct the deposition of the water, and small crown density, which reduces 


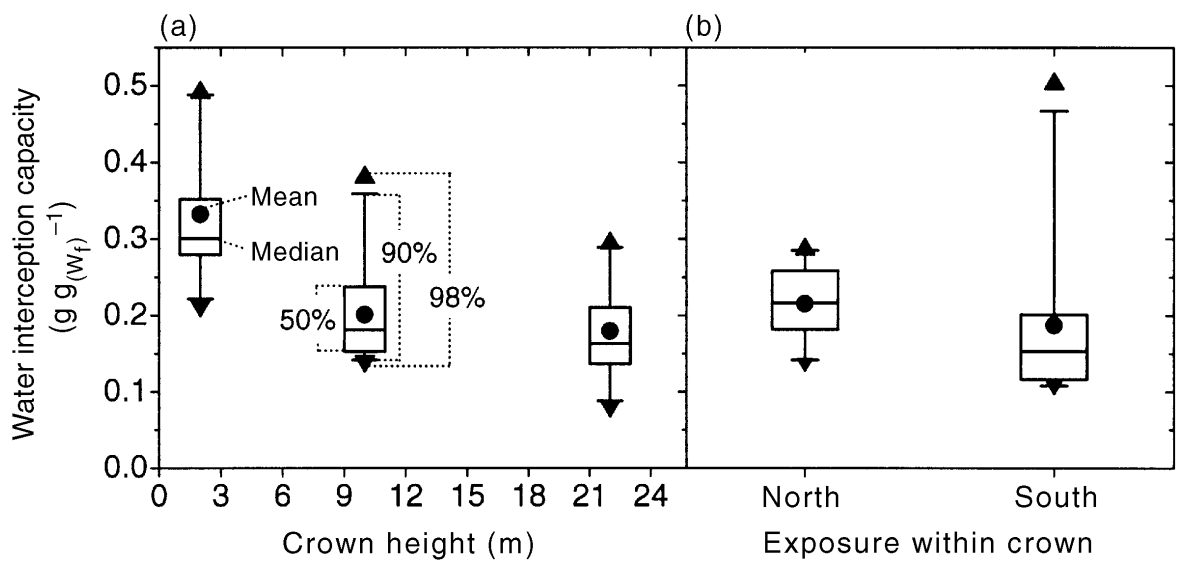

(c)

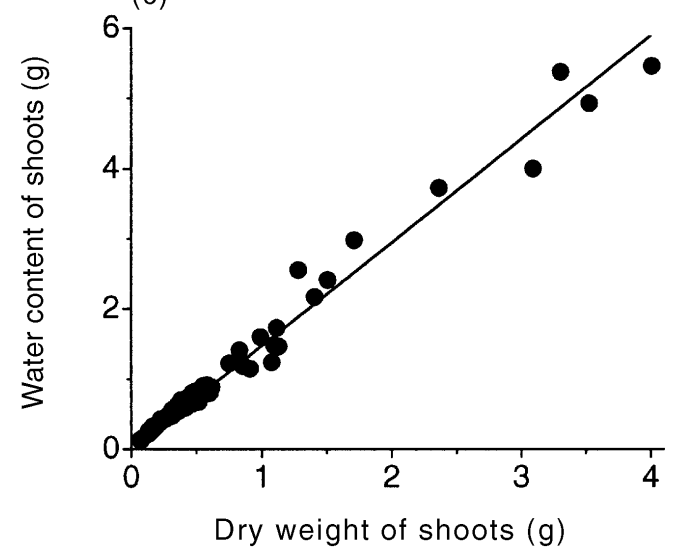

Fig. 9. Capacity for water deposition (based on fresh weight $W_{f}$ ) of current-year twigs (1992) in dependence on (a) crown height at west exposure and (b) crown exposure at the height of $10 \mathrm{~m}$ aboveground. Box plots show: means, medians, and ranges of scatter for $50 \%, 90 \%$ and $98 \%$ of samples. (c) Relationship between water content and dry matter in the twigs used to determine the capacity for water deposition $(y=1.47 \mathrm{x}$, $\left.r^{2}=0.98, n=71\right)$. the capacity for such deposition. Hence, its effect on transpiration is complex. The following factors seem to be the determining ones: (i) the coupling of the transpiring part of the crown to the free atmosphere; (ii) the crown's capacity for water deposition; and (iii) the quantity, frequency and mode (e.g. dew, fog, rain) of precipitation. Since the deposition and subsequent evaporation of water occurs most rapidly in the exposed parts of the crowns, transpiration there is affected most but with little lasting effect (Herzog et al. 1994). In a subalpine climate, which has frequent slight precipitation and a great deal of fog, it is in the rough and thin canopy type, as presented here, that transpiration is particularly affected by interception (cf. McNaughton \& Jarvis 1983).

Twigs in the sun have numerous xeromorphic characteristics. In contrast, those in the shade are fine and light. Shaded twigs may be highly decoupled from the free atmosphere and poorly adapted to radiative and evaporative stress (Brehmer 1981). We found that these twigs had a larger capacity for water deposition than twigs in the sun (Fig. 9). Thus, their fine structure may be regarded as being optimized not only for the harvesting of light (e.g. Carter \& Smith 1985), but also for the external binding of water. While sun twigs, from which intercepted water usually evaporates quickly, may overcome rapid changes in evaporative demand (light-flecks) by drawing on internal reserves, shaded twigs with little such reserves may profit from the external water. This may be of particular importance for them because their hydraulic conductivity, which determines the internal water supply, is more limited than that of sun twigs (Brehmer 1981; Sellin 1988). Because of their small stomatal aperture (Jarvis 1980) and their canopy-protected location, they can be considered to follow the strategy of avoiding drought stress. Their ability to bind a substantial amount of external water thereby helps to avoid strain (sensu Levitt 1980).

Lichens populated the crowns at our experimental site. They grew with increasing density towards their tops. Lichen thalli, similar to a sponge, were able to absorb water. The transpi- 
ration of this water took longer than the evaporation of the water from twig sufaces. This meant they provided a long-term source of water and humidified the microenvironment of the needles. Thus, lichens played a symbiotic role by moderating the evaporative demand in exposed parts of the crowns. At the same time, they profited from the favorable light conditions.

A striking example of the diurnal variability in transpiration within the experimental tree was observed on 28 August (Fig. 3). Because the northern part of the crown was downwind and partially decoupled from evaporative forces, the water intercepted there evaporated slowly, thus contributing to a one-sided transpiration. In contrast, the weather on 17 September gave rise to a fairly homogeneous transpiration. The lasting effect on transpiration of the water intercepted by the shade crown could be observed after heavy rain on the first days of September (Fig. 4). However, it is not clear whether the enhanced water deposition capacity of shaded twigs or their decoupling from evaporative forces contributed more to the reduction in transpiration.

In spite of great diurnal variability, the different parts of the crown over longer periods transpired in fairly constant proportions (Fig. 8b and 8c). Schulze et al. (1985) found that the average transpiration of a crown was $12 \%$ less than the transpiration of a single sun twig. Our estimate yielded a $36 \%$ smaller average transpiration of the entire crown than of the upper half of it. In both studies, the trees had a height of $25 \mathrm{~m}$. While the living crown of the tree studied by Schulze $e t$ al. (1985) extended from the top to $16 \mathrm{~m}$ aboveground, the crown examined by us started $3.5 \mathrm{~m}$ aboveground. The considerably lower and larger shaded crown included in our measurement may explain some of the difference in the percentages. However, Schulze et al. (1985) determined the transpiration of the twig by gas exchange, whereas that of the whole crown was derived from sap flow in xylem. It is known that the two methods of estimating transpiration are of limited comparability (e.g. Dugas et al. 1993; Goulden \& Field 1994). The present study provides further evidence that gas exchange, whereby leaves are enclosed and kept dry, is of little use for estimating the natural transpiration in a wet climate.
During the night of 22-23 September (Fig. 6), sap flow only decreased slowly due to Foehn winds and even continued during a spell of rain between $0 \mathrm{~h}$ and $1 \mathrm{~h}$, until the wind ceased at $2 \mathrm{~h}$. A sap flow response to the wind at velocities of $6-10 \mathrm{~m} \mathrm{~s}^{-1}$ was also observed after rain in the morning of 1 September (Fig. 4). Thus, wind induced some transpiration even in the wet crown, and also during the night. At our particular subalpine location, water in the soil was always plentiful. Nights were usually cold and humid, so stomata may have remained open then. An indicator of this was the nocturnal sap flow during the Foehn, which considerably exceeded that resulting from nightly resaturation of the tree.

Sap flow in the middle of stem $\mathrm{N}$ regularly underwent a temporary decline in the morning (Fig. 4 and 5). This cannot be explained by external factors, such as shading, and it seems to result from a restricted supply of water to the crown top. Such a restriction could result from an abruptly increased transport distance for the water when the internal reserves were depleted and the water had to be drawn all the way up from the soil. At the same time, the lower parts of the crown started transpiring, and so may have competed for this water. The competition for water within a crown has also been described by Hinckley and Ritchie (1970) for the northern and southern parts of Abies amabilis.

It may be assumed that the shortage of water in the top of the crown caused a reduction in stomatal conductance there. If this had not been the case, a water imbalance, and thus foliar injury, would have been likely. However, such a stomatal response in the top of the tree would have occurred even before the sap in its base started moving (see Fig. 4). Hence, it could not be induced by chemical root signals (cf. Reich \& Hinckley 1989; Tardieu \& Davies 1993), so it might have a local origin. Further, the mechanism suggests that a lack of proper stomatal functioning (cf. Maier-Maercker \& Koch 1992) would have serious consequences, particularly for the top of the crown. It also indicates a significant resistance in the water transport from soil to leaves, which goes against Schulze et al. (1985) but which is in agreement with findings for Pinus contorta (Running 1980) and also with observations on Picea abies (Herzog 1995). 
However, the top of the crown seemed to temporarily escape the limitation in water uptake and transpired considerable reserves of water stored within the crown. These reserves were refilled during subsequent nights and wet weather (cf. Herzog et al. 1994; Herzog et al. 1995). The phenomenon whereby water is lifted from the soil up to stores in the lower crown at night in order to be withdrawn by its top the following morning is reminiscent of the way water is redistributed by the roots at night, which is called 'hydraulic lift' (Caldwell \& Richards 1989). By analogy with this effect, a staggered lift in the aboveground transport as well may significantly improve the effectiveness of water gain for the crown. It reveals an interesting aspect of the water relations of tall trees, since numerous questions still remain concerning the ascent of sap within these trees.

\section{ACKNOWLEDGEMENTS}

We would like to thank the Swiss Federal Office of Environment, Forests and Landscape (BUWAL) for kindly providing the weather data, Professor Dr H. Flühler and Professor Dr R. Webster for critical comments on the manuscript and Dr J. Innes, Mrs M. J. Sieber and Dr S. Dingwall for correcting the English.

\section{REFERENCES}

BALdocchi D. (1989) Canopy-atmosphere water vapour exchange: Can we scale from a leaf to a canopy? In: Proceedings of a workshop on estimation of areal evapotranspiration. Vancouver, Canada, August 1987. (eds T. A. Black, D. L. Spittlehouse, M. D. Novak \& D. T. Price) International Association of Hydrological Science Publication 177: 21-40.

Balek J., Čermák J., Kučera \& Prax A. (1983) A direct method for forest transpiration measurement. Journal of Hydrology 66: 123-131.

Beier C., Hansen C. B. K. \& Gundersen P. (1993) Spatial variability of throughfall fluxes in a spruce forest. Environmental Pollution 81: 257-267.

BLACK T. A. (1979) Evapotranspiration from Douglas Fir stands exposed to soil water deficits. Water Resources Research 15: 164-170.
BRehMeR U. (1981) Licht- und Schattennadeln der Fichte (Picea abies (L.) Karst.). Beiträge zu Anatomie, Morphologie und Wasserhaushalt. Dissertation an der Forstwissenschaftlichen Fakultät der LudwigMaximilians-Universität, München (in German).

Caldwell M. M. \& Richards J. H. (1989) Hydraulic lift: water efflux from upper roots improves effectiveness of water uptake by deep roots. Oecologia 79: 1-5.

Carter G. A. \& Smith W. K. (1985) Influence of twig structure on light interception and photosynthesis in conifers. Plant Physiology 79: 1038-1043.

Čermák J., Deml M. \& Penka M. (1973) A new method of sap flow rate determination in trees. Biologia Plantarum 15: 171-178.

ČERMÁK J. \& KuČera J. (1981) The compensation of natural temperature gradient at the measuring point during the sap flow rate determination in trees. Biologia Plantarum 23: 469-471.

Denmead O. T. (1984) Plant physiological methods for studying evapotranspiration: problems of telling the forest from the trees. Agricultural Water Management 8: 167-189.

Diawara A., Loustau D. \& Berbigier P. (1991) Comparison of two methods for estimating the evaporation of a Pinus pinaster (Ait.) stand: sap flow and energy balance with sensible heat flux measurements by an eddy covariance method. Agricultural and Forest Meteorology 54: 49-66.

Dugas W. A., Wallace J. S., Allen S. J. \& Roberts J. M. (1993) Heat balance, porometer and deuterium estimates of transpiration from potted trees. Agricultural and Forest Meteorology 64: 47-62.

Gerdes G., Aluison B. E. \& Pereira L. S. (1994) Overestimation of soybean crop transpiration by sap flow measurements under field conditions in Central Portugal. Irrigation Science 14: 135-139.

Goulden M. L. \& Field C. B. (1994) Three methods for monitoring the gas exchange of individual tree canopies: ventilated-chamber, sap-flow and Penman-Monteith measurements on evergreen oaks. Functional Ecology 8: 125-135.

Granier A. (1985) Une nouvelle méthode pour la mesure du flux de sève brute dans le tronc des arbres. Annales des Sciences Forestieres 42: 193-200 (in French).

Granier A. (1987) Evaluation of transpiration in a Douglas-fir stand by means of sap flow measurements. Tree Physiology 3: 309-320.

Gutiérrez M. V., Harrington R. A., Meinzer F. C. \& Fownes J. H. (1994) The effect of environmentally induced stem temperature gradients on transpiration estimates from the heat 
balance method in two tropical woody species. Tree Physiology 14: 179-190.

Häsler R., SAvi C. \& Herzog K. (1991) Photosynthese und stomatäre Leitfähigkeit der Fichte unter dem Einfluss von Witterung und Luftschadstoffen. In: Luftschadstoffe und Wald. Band 5. Ergebnisse aus dem Nationalen Forscbungsprogramm 14 (ed. M. Stark) pp. 143-168. Verlag der Fachvereine, Zürich (in German).

Herzog K. M. (1995) Water relations of a mature subalpine Norway spruce (Picea abies (L.) Karst.). $\mathrm{PhD}$ dissertation no. 11126. Swiss Federal Institute of Technology, Zürich.

Herzog K. M., Häsler R. \& Thum R. (1995) Diurnal changes in the radius of a subalpine Norway spruce stem: their relation to the sap flow and their use to estimate transpiration. Trees 10: 94-101.

Herzog K. M., Thum R. \& Häsler R. (1994) Diurnal variation in stem radii and transpiration flow at different crown levels of a Norway spruce (Picea abies (L.) Karst.). In: Verbandlungen der Gesellschaft für Ökologie. Band 23 (ed. J. Pfadenhauer) pp. 143-147. Gesellschaft für Ökologie, Freising-Weihenstephan.

Herzog K. M., Thum R., Zweifel R. \& Häsler R. (1997) Heat balance measurements-to quantify sap flow in thin stems only? Agricultural and Forest Meteorology 83: 75-94.

Hinckley T. M., Lassoie J. P. \& Running S. W. (1978) Temporal and spatial variations in the water status of forest trees. Forest Science Monograph 20: 3738.

Hinckley T. M. \& Ritchie G. A. (1970) Withincrown patterns of transpiration, water stress, and stomatal activity in Abies amabilis. Forest Science 16: 490-492.

JArvis P. G. (1980) Stomatal response to water stress in conifers. In: Adaptations of plants to water and high temperature stress (eds N. C. Turner \& P. J. Kramer), pp. 105-122. John Wiley and Sons, New York.

Jarvis P. G. \& CATSKY J. (1971) Assimilation chambers and the scope and limitation of their application. In: Plant photosynthetic production. Manual of methods (eds Z. Sestak, J. Catsky \& P. G. Jarvis) pp. 58-59. Dr W. Junk Publishers, The Hague.

KozLowski T. T. (1979) Tree Growth and Environmental Stresses. University of Washington Press, Seattle.

Kučera J., Čermák J \& PenKa M. (1977) Improved thermal method of continual recording the transpiration flow rate dynamics. Biologia Plantarum 19: 413-420.

Leviti J. (1980) Stress terminology. In: Adaptation of plants to water and high temperature stress (eds N. C. Turner \& P. J. Kramer) pp. 437-439. John Wiley and Sons, New York.
Lovett G. M. \& Reiners W. A. (1986) Canopy structure and cloud water deposition in subalpine coniferous forests. Tellus 38B: 319-327.

Maier-Maercker U. \& Koch W. (1992) The effect of air pollution on the mechanism of stomatal control. Trees 7: 12-25.

Matyssek R., Čermák J. \& KuČera J. (1991) Ursacheneingrenzung eines lokalen Buchensterbens mit einer Messmethode der Kronentranspiration. Schweizerische Zeitschrift für das Forstwesen 142: 809-828 (in German).

McNaughton K. G. \& Jarvis P. G. (1983) Predicting effects of vegetation changes on transpiration and evaporation. Water Deficit and Plant Growth 7: 1-42.

Reich P. B. \& Hinckley T. M. (1989) Influence of pre-dawn water potential and soil-to-leaf hydraulic conductance on maximum daily leaf diffusive conductance in two oak species. Functional Ecology 3: 719-726.

RuNNING S. W. (1980) Field estimates of root and xylem resistances in Pinus contorta using root excision. Journal of Experimental Botany 31: 555-569.

SAKURATANi T. (1984) Improvement of the probe for measuring water flow rate with the stem heat balance method. Journal of Agricultural Meteorology 40: 273-277.

Schoettle A. W. \& Smith W. K. (1991) Interrelation between shoot characteristics and solar irradiance in the crown of Pinus contorta ssp. latifolia. Tree Physiology 9: 245-254.

Schulze E.-D., Čermák J., Matyssek R. et al. (1985) Canopy transpiration and water fluxes in the xylem of the trunk of Larix and Picea trees-a comparison of xylem flow, porometer and cuvette measurement. Oecologia 66: 475-483.

Sellin A. A. (1988) Hydraulic architecture of Norway spruce. Soviet Plant Physiology 35: 839-845.

Stark M., Primault B. \& Schüpbach E. (1991) Die Beobachtungsflächen an der Lägeren, im Alptal und in Davos. In: Luftschadstoffe und Wald. Band 5. Ergebnisse aus dem Nationalen Forschungsprogramm 14 (ed. M. Stark) pp. 15-24. Verlag der Fachvereine, Zürich (in German).

SWANSON R. H. (1994) Significant historical developments in thermal methods for measuring sap flow in trees. Agricultural and Forest Meteorology 72: 113-132.

TARdiEu F. \& Davies W. J. (1993) Integration of hydraulic and chemical signalling in the control of stomatal conductance and water status of droughted plants. Plant, Cell and Environment 16: 341-349.

Valentini R., Scarascia-Mugnozza G. E. \& Sabatti M. (1989) Evapotranspiration measurements in a Mediterranean forest stand by means of 
ecophysiological and microclimatic techniques. Annales des Sciences Forestières 46 (Suppl.) 325s-329s.

VogT R. \& JAEger L. (1990) Evaporation from a pine forest - using the aerodynamic method and Bowen ratio method. Agricultural and Forest Meteorology 50: 39-54.
WANG Y. P. \& JARvis P. G. (1990) Influence of crown structural properties on PAR absorption, photosynthesis, and transpiration in Sitka spruce: application of a model (MAESTRO). Tree Physiology 7: 297-316. 